\title{
Evaluation of an aerosol optical scheme in the chemistry-transport model CHIMERE
}

\author{
J.C. Pérée ${ }^{\mathrm{a}, \mathrm{b}, *}$, M. Mallet ${ }^{\mathrm{a}}$, V. Pont ${ }^{\mathrm{b}}$, B. Bessagnet ${ }^{\mathrm{a}}$ \\ anstitut National de l'Environnement Industriel et des Risques, Parc technologique Alata, 60550 Verneuil en Halatte, France \\ ${ }^{\mathrm{b}}$ Laboratoire d'Aérologie, Université de Toulouse, Toulouse, France; Laboratoire d'Aérologie, CNRS, Toulouse, France
}

\begin{abstract}
This paper presents an aerosol optical scheme developed in the chemistry-transport model CHIMERE dedicated to calculate optical properties of particles. Such developments are very helpful as they complement the usual validation with PM (Particulate Matter) ground-based measurements by using surface (AERONET/PHOTONS network) and satellite (MODIS) remote sensing observations. To reach this goal, Aerosol Optical Thickness (AOT), column-averaged Single Scattering Albedo (SSA) and asymmetry parameter (g) are calculated at $440 \mathrm{~nm}, 675 \mathrm{~nm}, 870 \mathrm{~nm}$ and $1020 \mathrm{~nm}$ (AERONET wavelengths) under three hypotheses on the particle mixing state (external, internally homogeneous and core-shell). Furthermore and in addition to optical calculations, an original development has been made to estimate column volume size distributions in CHIMERE, directly comparable with AERONET retrievals. Comparisons between simulations and observations are made over Western Europe for the year 2003 but also for one specific case focused on ammonium nitrate aerosols. Observed AOT display a seasonal cycle (with highest values during summer) rather well reproduced by the model but biases with observational data have been found depending on seasons. In fall, winter and early spring, modeled AOT values agree well with AERONET retrievals with small negative biases. Focus on a pollution episode of ammonium nitrate origin during March 2003 reveals that CHIMERE is able to well reproduce the fine mode volume size distribution retrieved by AERONET, leading to good agreements between modeled and observed AOT. In late spring and summer, AERONET AOT values are underpredicted by the model, which could be due to uncertainties in modeling secondary species.
\end{abstract}

\section{Introduction}

It is now well recognized that particulate pollution is a real concern for human health as chemical and physical interactions of aerosols with lung tissus can induce irritations or damages (Barrett et al., 2008). Adverse health effects can occur after short-term exposure to concentration peaks as well as long term exposure to relatively low concentrations. For the year 2004, European Union limited values for daily $\left(50 \mu \mathrm{g} \mathrm{m}^{-3}\right)$ and annual $\left(40 \mu \mathrm{g} \mathrm{m}^{-3}\right)$ average PM10 (aerosol with diameter less than $10 \mu \mathrm{m}$ ) surface concentrations were exceeded in both urban and rural locations across Europe (Adams et al., 2007). Moreover, fine fraction of aerosols such as PM2.5 or PM1 (aerosol with diameters less than 2.5 and $1 \mu \mathrm{m}$, respectively) is paid much attention as it can penetrate deep into

\footnotetext{
* Corresponding author at: Institut National de l'Environnement Industriel et des Risques, Parc technologique Alata, 60550 Verneuil en Halatte, France. Tel.: +3303 446182 52; fax: +330344556699.

E-mail address: jean-christophe.PERE@ineris.fr (J.C. Péré).
}

the human respiratory and cardio-vascular system (Polichetti et al., 2009). Hence, efficient emission control strategies are an important challenge for environmental policies.

By predicting spatial and temporal distribution of particulate pollutants, air quality models are useful tools for air quality management. However, modeling aerosol properties with a high degree of accuracy remains a challenging task because of the complexity of particle sizes, chemical composition and degree of mixing. As health effects of air pollution are mainly due to fine particles, a key issue in air quality modeling is to accurately determine the fine fraction of aerosols. Nucleation, condensation/ evaporation, coagulation and deposition processes are sources of errors in modeling particle size evolution. Also, the treatment of the mixing state of particles can have an impact on their modeled optical properties and on their chemical reactivity (Mallet et al., 2004; Vester et al., 2007; Dey et al., 2008. Some recent works (Sheer et al., 2005; Gyawali et al., 2009) showed that urban and industrial black carbon (BC) particles are externally mixed near the source of emissions and tend to grow by coagulation with other particles during transport to form an internally mixture of aerosols. 
Many processes influencing aerosol population are still not well described. Indeed, the formation of secondary organic aerosols (SOA), which are recognized to represent more than $60 \%$ of the total carbonaceous aerosol over Europe in rural sites during summer (Gelencser et al., 2007), is poorly understood. Some reasons are uncertainties in volatile organic compounds (VOC as SOA precursors) emissions and poorly known chemical processes leading to their oxidation (Hallquist et al., 2009). The mixing of chemical species also modifies the hydrophobic/hydrophilic properties of the particle, which in turn affect its growth ability. For instance, an external mixture of black carbon is mostly hydrophobic while coating with sulfate, nitrate or organic aerosols increases its water affinity (Zhang et al., 2008; Khalizov et al., 2009).

Hence, facing the challenge of aerosol modeling, increasingly detailed air quality numerical models have been developed in the past few decades (Schaap et al., 2004; Bessagnet et al., 2004; Mallet et al., 2007). An important stage in the development of such models is to evaluate their performances with as much as observational data as available. The air quality monitoring network coordinated by EMEP (European Monitoring and Evaluation Programme) (see EMEP web site: http://www.emep.int/) and AirBase (European Air quality dataBase) (see AirBase web site: http://airclimate.eionet.europa.eu/databases/airbase/) was developed in Europe. It supplies regular and reliable measurements of some gaseous and particulate pollutants $\left(\mathrm{O}_{3}, \mathrm{H}_{2} \mathrm{SO}_{4}, \mathrm{NO}_{3}, \mathrm{NH}_{4}, \mathrm{PM} 2.5\right.$ and PM10) used for model validation. However, the set of measured parameters is not numerous enough to give a complete description of the aerosol characteristics, such as a detailed aerosol chemical composition and fine fraction. In that sense, aerosol optical properties can be used for air quality model validation as they are strongly related to aerosol concentration, chemical composition, size distribution and degree of particle mixing (Garland et al., 2009). In that frame, the AErosol RObotic NETwork (AERONET), which consists in about 200 photometers spread over all continents, provides measurements of key aerosol properties (Dubovik et al., 2000; Holben et al., 2001) and represents a new way for air quality model evaluation. These instruments retrieve columnar characteristics of the aerosol population such as volume size distribution and optical properties as aerosol optical thickness (AOT) (column integrated aerosol extinction), single scattering albedo (SSA) (ratio of scattering to (scattering + absorption)) and asymmetry parameter $(\mathrm{g})$ (angular distribution of scattered light) at four wavelengths $(440 \mathrm{~nm}, 675 \mathrm{~nm}, 870 \mathrm{~nm}$ and $1020 \mathrm{~nm}$ ) (Dubovik and King, 2000). SSA is a relevant parameter for characterizing absorbing properties of the aerosol population. Indeed, SSA decreases (in the visible radiation) for growing proportion of absorbing particles such as black carbon aerosol (Höller et al., 2000). Also, increasing SSA values from visible to infrared wavelengths indicate influence of dust particles (Dubovik et al., 2001). In addition, the asymmetry parameter is also a useful indicator of the aerosol type, with larger values for coarse particles (at a given wavelength).

Moreover, regional information on vertically integrated particle loading can be obtained from satellite observations as AOT is now well retrieved from sensors such as Moderate Resolution Imaging Spectroradiometer (MODIS) (Engel-Cox et al., 2004).

This study presents an aerosol optical scheme developed as a complementary evaluation tool of the chemistry-transport model CHIMERE (Vautard et al., 2001; Bessagnet et al., 2004). This aerosol optical module has been built to calculate specifically aerosol optical properties directly comparable with AERONET (Dubovik et al., 2000) and satellite inversions. It computes AOT, columnaveraged SSA and $g$ at the four AERONET wavelengths $(440 \mathrm{~nm}$, $675 \mathrm{~nm}, 870 \mathrm{~nm}$ and $1020 \mathrm{~nm}$ ) for three types of aerosol mixings: external, internally homogeneous and core-shell. Furthermore and in addition to optical calculations, an original development has been made for calculating column volume size distributions in CHIMERE, directly comparable with AERONET volume size distributions (Dubovik et al., 2000). We clearly demonstrate in this work the utility of such developments as air quality models are usually evaluated with PM10 and PM2.5 databases, without considerations on the detailed aerosol size distribution.

The paper is structured as follows. In Section 2, the CHIMERE aerosol module is presented including the computation of the aerosol volume size distribution along with the modeling of the optical properties under the three assumptions on the particle mixing state. In Section 3, we describe the observational data of AERONET sunphotometers and MODIS sensor used in this study. Then, in Section 4, comparisons between modeled and observed aerosol chemical composition, size distribution and optical properties are discussed for all the year 2003 and also for one specific pollution event focused on ammonium nitrate aerosols.

\section{CHIMERE aerosol module}

\subsection{Aerosol module}

Given a set of NOx, SOx, NH3, PM, VOC's and CO emissions, the chemistry-transport model CHIMERE (Vautard et al., 2001) calculates the concentrations of gas-phase and aerosols species. The dynamics and gas-phase parts of the model (see Schmidt et al., 2001) have successively been improved (Vautard et al., 2003, 2005). The full model documentation for the updated version can be found at: http://www.Imd.polytechnique.fr/chimere/. The aerosol module, described in Bessagnet et al. (2004), calculates concentrations of 10 chemical species: sulfates, nitrates, ammonium, primary organic and black carbon (OC and $\mathrm{BC}$ ), secondary organic aerosols, sea salt, natural and anthropogenic dust and water. The gas-particle partitioning of the ensemble Sulfate/ Nitrate/Ammonium is treated by the code ISORROPIA (Nenes et al., 1998) implemented in CHIMERE. OC and BC emissions are issued from the methodology in Junker and Liousse (2008) study. In 2003, important wildfires affected Western Europe with more than 650,000 ha of forest area and about 45,000 ha of agricultural land destroyed. In this study, particulate matter and trace gases (such as $\mathrm{CO}, \mathrm{VOC}, \mathrm{NO}, \mathrm{NO}_{2}$, etc.) released into the atmosphere by fires are taken into account according to the methodology described in Hodzic et al. (2007). Anthropogenic dust emissions are taken from EMEP inventory and natural dust are transported from boundary conditions calculated on a monthly base, and are locally produced within the domain after Vautard et al. (2005). SOA formation is represented according to oxidation of relevant precursors and gasparticle partitioning of the condensable oxidation products. The chemical scheme includes precursors of biogenic (such as isoprene, terpene, etc.) and anthropogenic (such as benzene, toluene, etc.) origin. VOC and NO emissions from vegetation are calculated using the Model of Emissions of Gases and Aerosols from Nature (MEGAN) (Guenther et al., 2006). The gas-particle partitioning formulation of Pun et al. (2006) has been adapted to the SOA formation mechanism implemented in CHIMERE (Bessagnet et al., 2009). The particle size distribution ranges from about $40 \mathrm{~nm}$ to $10 \mu \mathrm{m}$ and is distributed into 12 bins. Dynamical processes influencing aerosol population such as coagulation, condensation/ evaporation, adsorption/desorption, wet and dry deposition and scavenging are also taken into account.

In the CHIMERE model, an original algorithm was developed (see equation (1)) to calculate an aerosol column volume size distribution $(\mathrm{d} V / \mathrm{d} \log (r))$ directly comparable to the column volume size distribution retrieved by AERONET: 


$$
\begin{aligned}
& \frac{\mathrm{d} V}{\operatorname{dlog}(r)}\left(\mu \mathrm{m}^{3} \times \mu \mathrm{m}^{-2}\right) \\
& =\left\{\sum_{k=1}^{k=n l} \frac{\sum_{c=1}^{c=C \max } \frac{m_{i}(c)}{\rho_{i}(c)} \times H(k)}{\log \left(r_{i, \text { max }}\right)-\log \left(r_{i, \min }\right)}\right\}_{\operatorname{bin}(i) \quad i=1, \ldots, 12}
\end{aligned}
$$

where $m_{i}(\mathbf{c})$ and $\rho_{i}(c)$ are respectively the mass concentration and the density of modeled species $\mathrm{c}$ in the bin $i$ (values of density of each chemical specie used in this work are displayed in Table 1). Cmax $(=10)$ is the total number of modeled chemical species (including the aerosol liquid water content) in each bin, $r_{i, \min }$ and $r_{i, \max }$ are the minimum and maximum radius of the size bin $i . H(k)$ is the width of the modeled vertical layer $k$ and $n l$ is the total number of layer.

In this study, a version of CHIMERE for a domain covering the Western Europe is used. The model grid ranges from $14^{\circ} \mathrm{W}$ to $28^{\circ} \mathrm{E}$ and from $35^{\circ} \mathrm{N}$ to $58.2^{\circ} \mathrm{N}$ with a 0.4 degree resolution both in latitude and longitude. The vertical grid contains 8 layers from surface to $500 \mathrm{hPa}$. The meteorological fields required by CHIMERE such as 3D winds, temperature, humidity and cloud water content are generated by the 5th Penn State mesoscale meteorological model MM5 (Dudhia, 1993) run over Europe with a $54 \mathrm{~km}$ resolution.

\subsection{Optical module}

\subsubsection{Mixing hypotheses}

Computing the complex refractive index of a particle requires to make an assumption on the mixing state of the aerosol chemical species. In this study, three different mixing states are modeled: external, internally homogeneous and core-shell mixing. The real and imaginary parts of the refractive indexes of each aerosol specie used to perform our simulations are reported in Table 1.

\section{- External mixing}

In the external treatment, there is no coagulation process between aerosols. Hence, each modeled particle consists in only one chemical substance. The extinction, scattering and absorption efficiency of a given species is calculated in each size bin using the Mie code published by Voshchinnikov (2004). The simulated optical efficiencies of the particle are the sum of all the optical efficiencies of the different aerosol chemical species (Hess et al., 1998).

\section{- Internally homogeneous mixing}

In this mixing state, the different chemical species are wellmixed in each size bin. To reflect the chemical and optical average of the aerosol population, a volume-weighted complex refractive index is calculated from the refractive index of pure species (Lesins et al., 2002). A mean particle density is similarly determined. The optical efficiencies of the particle are computed using the Mie code for homogeneous sphere of Voshchinnikov (2004). The optical properties of the total aerosol population are then retrieved using the methodology developed by Wu et al. (1996) for a sectional aerosol distribution.

\section{- Core-shell mixing}

The hypothesis of an internally homogeneous mixing seems to be unphysical as BC can not be well-mixed in the particle because of its complex geometry (Sachdeva and Attri, 2007). Thus, in the coreshell mixing, each particle is assumed to have a structure as follows: primary aerosols (soot and mineral dust) are assumed to be the core. Here, soot is referenced as a mixture of BC and OC (Jacobson, 2000). Secondary particles (sulfates, nitrates, ammonium, secondary organic aerosols), sea salt and water are assumed to form the shell material. Coating of soot with secondary particles has recently been observed over Western Europe by Vester et al. (2007). Similar observations have been made in Mexico City by Adachi and Buseck (2008) and near Tokyo by Shiraiwa et al. (2007) who show that soot aerosols are generally coated by organic matter and sulfates.

The real and imaginary parts of the refractive index of the core and the shell have been determined using a volume average procedure (Lesins et al., 2002). For each size bin, we calculate the volume fraction of the core $(\mathrm{BC}+\mathrm{OC}+\mathrm{Dust})$ and the shell (sulfate + nitrate + ammonium + SOA + sea salt + water) as follows:

$$
\begin{aligned}
f_{\text {core }}= & \left(V_{\mathrm{BC}}+V_{\mathrm{OC}}+V_{\text {Dust }}\right) / V_{\text {total }} \\
f_{\text {shell }}= & \left(V_{\text {sulfate }}+V_{\text {nitrate }}+V_{\text {ammonium }}+V_{\mathrm{SOA}}\right. \\
& \left.+V_{\text {seasalt }}+V_{\text {water }}\right) / V_{\text {total }}
\end{aligned}
$$

Hence, the volume of the core and the shell can vary with the size of the particle as volume of chemical species can differ from a size bin to another due to physical processes influencing aerosol population such as nucleation, coagulation, condensation/evaporation, adsorption/desorption and deposition.

Here, the extinction, scattering and absorption efficiencies of a single particle are computed using the Mie algorithm for $n$ layered spheres of Wu and Wang (1991) and the optical properties

\begin{tabular}{|c|c|c|c|c|c|}
\hline \multirow[b]{2}{*}{ Specie } & \multirow[t]{2}{*}{ Density } & \multicolumn{4}{|c|}{ Complex refractive index $(n-i k)$} \\
\hline & & $440 \mathrm{~nm}$ & $675 \mathrm{~nm}$ & $870 \mathrm{~nm}$ & $1020 \mathrm{~nm}$ \\
\hline Nitrate & $1.7^{\mathrm{a}}$ & $1.53-\mathrm{i} 0.006^{\mathrm{b}}$ & $1.53-\mathrm{i} 0.006$ & $1.53-\mathrm{i} 0.006$ & $1.53-0.006$ \\
\hline Ammonium & $1.7^{\mathrm{a}}$ & $1.52-\mathrm{i} 0.0005^{\mathrm{c}}$ & $1.52-\mathrm{i} 0.0005$ & $1.52-\mathrm{i} 0.0005$ & $1.51-\mathrm{i} 0.0005$ \\
\hline Sulfate & $1.84^{\mathrm{c}}$ & $1.44-\mathrm{i} 10^{(-8) \mathrm{c}}$ & $1.43-\mathrm{i} 2.6 \times 10^{-8}$ & $1.43-\mathrm{i} 1.7 \times 10^{-7}$ & $1.50-\mathrm{i} \times 10^{-8}$ \\
\hline OC & $1.5^{\mathrm{d}}$ & $1.45-\mathrm{i} 0.001^{\mathrm{c}}$ & $1.45-\mathrm{i} 0.001$ & $1.45-\mathrm{i} 0.001$ & $1.45-\mathrm{i} 0.001$ \\
\hline $\mathrm{BC}$ & $1.5^{\mathrm{d}}$ & $1.87-0.569^{\mathrm{e}}$ & $1.87-0.569$ & $1.87-0.569$ & $1.87-0.569$ \\
\hline SOA & $1.5^{\mathrm{d}}$ & $1.45-\mathrm{i} 0.001^{\mathrm{c}}$ & $1.45-\mathrm{i} 0.001$ & $1.45-\mathrm{i} 0.001$ & $1.45-\mathrm{i} 0.001$ \\
\hline Sea salt & $2.1^{\mathrm{c}}$ & $1.45-\mathrm{i} 0.0056^{\mathrm{c}}$ & $1.45-\mathrm{i} 5 \times 10^{-5}$ & $1.45-\mathrm{i} 5 \times 10^{-5}$ & $1.45-\mathrm{i} 1.2 \times 10^{-4}$ \\
\hline Dust & $2.3^{\mathrm{b}}$ & $1.52-\mathrm{i} 0.008^{\mathrm{c}}$ & $1.51-\mathrm{i} 0.008$ & $1.50-\mathrm{i} 0.008$ & $1.50-\mathrm{i} 0.008$ \\
\hline Water & $1.0^{c}$ & $1.34-\mathrm{i} 2 \times 10^{(-9) \mathrm{c}}$ & $1.33-\mathrm{i} 3.4 \times 10^{-8}$ & $1.33-\mathrm{i} 3.9 \times 10^{-7}$ & $1.32-\mathrm{i} 1.43 \times 10^{-6}$ \\
\hline
\end{tabular}
of the total aerosol distribution by using the methodology of $\mathrm{Wu}$ et al. (1996).

Table 1

Density and wavelength-dependent complex refractive index of each aerosol specie used in the CHIMERE optical module.

$n$ and $k$ are respectively the real and imaginary parts of the complex refractive index.

a See Sloane (1984).

b See d'Almeida et al. (1991).

c See Krekov (1993).

d See Horvath (1993).

e See Marley et al. (2001). 


\subsubsection{Modeling aerosol optical properties}

The optical module has been developed for direct comparisons with AERONET inversions, including the aerosol optical thickness for the total $\left(\mathrm{AOT}_{\text {tot }}\right)$ and fine $\left(\mathrm{AOT}_{\text {fine }}\right)$ aerosol size distribution, and column-averaged single scattering albedo and asymmetry parameter.

The extinction $\left(b_{\text {ext }}\right)$, scattering $\left(b_{\text {sca }}\right)$ and absorption $\left(b_{\mathrm{abs}}\right)$ coefficient of particles can be expressed as (Mie, 1908):

$b_{i}\left(m^{-1}\right)=\int_{R \min }^{R \max } \pi r^{2} Q_{i}(\lambda, m, f(r)) f(r) \mathrm{d} r \quad i=$ ext, sca, abs

where $r$ is the aerosol radius, $Q_{i}$ is the efficiency factor of the particle, which depends on the wavelength $\lambda$, the aerosol complex refractive index $\mathrm{m}$ and the aerosol distribution function $f(r) . R_{\min }$ and $R_{\max }$ are respectively the minimum and maximum radius of the aerosol distribution.

\section{- Aerosol optical thickness}

The Aerosol Optical Thickness (at a wavelength $\lambda$ ) is defined as follows:

$\operatorname{AOT}(\lambda)=\int_{z_{0}}^{z_{\mathrm{TOA}}} b_{\mathrm{ext}}(\lambda, z) \mathrm{d} z$

where $z_{0}$ and $z_{\mathrm{TOA}}$ are respectively the altitude at ground level and at the top of atmosphere. In the optical module, a cut-off radius of $R_{\max }=0.6 \mu \mathrm{m}$ is used (in the $b_{\text {ext }}$ expression, see equation (2)) to calculate $\mathrm{AOT}_{\text {fine, }}$ which allows direct comparisons with $\mathrm{AOT}_{\text {fine }}$ retrieved by AERONET.

The spectral dependence of the aerosol optical thickness is given by the Angström exponent. For measurements of AOT $\left(\lambda_{1}\right)$ and AOT $\left(\lambda_{2}\right)$ taken at two wavelengths $\lambda_{1}$ and $\lambda_{2}$ respectively, the Angström exponent $\alpha\left(\lambda_{1}-\lambda_{2}\right)$ is given by:

$\alpha\left(\lambda_{1}-\lambda_{2}\right)=-\left[\frac{\log \left(\operatorname{AOT}\left(\lambda_{1}\right) / \operatorname{AOT}\left(\lambda_{2}\right)\right)}{\log \left(\lambda_{1} / \lambda_{2}\right)}\right]$

Coarse particles (such as mineral dust) are associated with alpha $(440-870 \mathrm{~nm})$ values less than 1 and vice versa for fine aerosols (Dubovik et al., 2001).

\section{- Single Scattering Albedo}

The Single Scattering Albedo is calculated as the ratio between the scattering and the extinction (scattering + absorption) coefficient. To make comparisons with AERONET observations, a columnaveraged SSA is modeled as follows:

$\operatorname{SSA}(\lambda)=\sum_{k=1}^{k=8} \mathrm{SSA}_{k} \times\left[\frac{b_{\mathrm{ext}, k}}{\sum_{k=1}^{k=8} b_{\mathrm{ext}, k}}\right]$

where $\mathrm{SSA}_{k}$ and $\mathrm{b}_{\text {ext, } k}$ are respectively the simulated single scattering albedo and extinction coefficient of the CHIMERE vertical layer $\mathrm{k}$.

\section{- Asymmetry parameter}

The asymmetry parameter $g$ is defined as the cosine-weighted average of the phase function, where the phase function is the probability of radiation being scattered in a given direction. $g$ vary from -1 for a complete backward scattering to 1 for a complete forward scattering. Values of $g$ are generally comprised between 0 and 1 for aerosols. As for the SSA, we have calculated a columnaveraged asymmetry parameter to make direct comparisons with $g$ values retrieved by AERONET: $g=\sum_{k=1}^{k=8} g_{k} \times\left[\frac{b_{\text {sca }, k}}{\sum_{k=1}^{k=8} b_{\text {sca }, k}}\right]$

where $\mathrm{g}_{k}$ and $\mathrm{b}_{\text {sca, } k}$ are respectively the modeled asymmetry parameter and the scattering coefficient of the layer $k$.

\section{Instrumental data}

\subsection{AERONET retrievals}

AERONET stations provide measurements of a large number of parameters characterizing aerosol population such as column volume size distribution and optical properties at four wavelengths (440 nm, $675 \mathrm{~nm}, 870 \mathrm{~nm}$ and $1020 \mathrm{~nm}$ ). AOT is retrieved for the total aerosol population $\left(\mathrm{AOT}_{\text {tot }}\right)$ and for both the fine $\left(\mathrm{AOT}_{\text {fine }}\right)$ and coarse ( $\left.\mathrm{AOT}_{\text {coarse }}\right)$ mode. The cut-off radius of $0.6 \mu \mathrm{m}$ is used as a separation point between fine and coarse aerosols. The uncertainty in $\mathrm{AOT}_{\text {tot }}, \mathrm{AOT}_{\text {fine }}$ and $\mathrm{AOT}_{\text {coarse }}$ measurements are respectively $\pm 0.01, \pm 0.02$ and \pm 0.015 , for $\lambda \geq 440 \mathrm{~nm}$ (Holben et al., 2001; Dubovik, 2010). As the uncertainty of \pm 0.015 is in the same order of magnitude than AERONET AOT $_{\text {coarse values usually observed over }}$ Europe during the year 2003, we do not use this AERONET inversion in our study.

The AERONET provides also the column averaged single scattering albedo. The associated uncertainty, at the four wavelengths, is \pm 0.03 when AOT $(440 \mathrm{~nm})$ is above 0.2 and \pm 0.07 otherwise (Dubovik et al., 2000). Based on these considerations, we estimate in our study a mean AERONET SSA associated to an average uncertainty $(\overline{\operatorname{SSA}}(\lambda) \pm \Delta(\operatorname{SSA}(\lambda)))$ as follows:

$\overline{\operatorname{SSA}}(\lambda)=\frac{1}{N} \sum_{i=1}^{i=N} \operatorname{SSA}_{i}(\lambda)$

$\Delta(\operatorname{SSA}(\lambda))=\frac{(n 1 \times 0.03)+(n 2 \times 0.07)}{N} N=n 1+n 2$

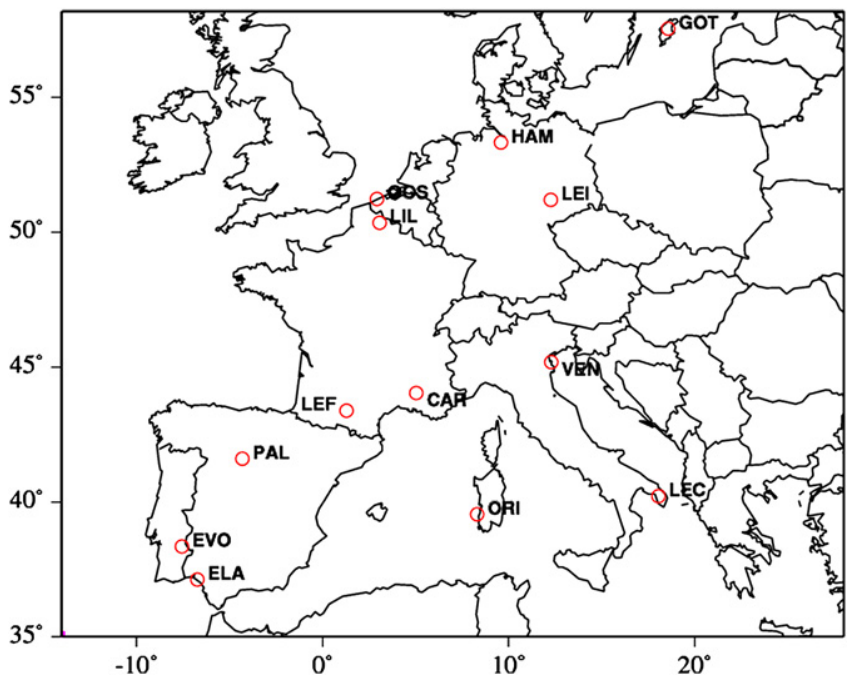

Fig. 1. Location of the 13 AERONET stations (circles) used in this study. ELA: El Arenosillo $\left(-6.73^{\circ} \mathrm{E}, 37.11^{\circ} \mathrm{N}\right)$, OOS: Oostende $\left(2.93^{\circ} \mathrm{E}, 51.23^{\circ} \mathrm{N}\right)$, LEF: Le Fauga $\left(1.29^{\circ} \mathrm{E}\right.$, $\left.43.38^{\circ} \mathrm{N}\right)$, HAM: Hamburg $\left(9.58^{\circ}\right.$ E, $\left.53.34^{\circ} \mathrm{N}\right)$, EVO: Evora $\left(-7.54^{\circ} \mathrm{E}, 38.34^{\circ} \mathrm{N}\right)$, PAL: Palencia $\left(-4.30^{\circ} \mathrm{E}, 41.59^{\circ} \mathrm{N}\right)$, ORI: IMC Oristano $\left(8.30^{\circ} \mathrm{E}, 39.54^{\circ} \mathrm{N}\right)$, LEC: Lecce University $\left(18.06^{\circ} \mathrm{E}, 40.20^{\circ} \mathrm{N}\right)$, VEN: Venise $\left(12.30^{\circ} \mathrm{E}, 45.18^{\circ} \mathrm{N}\right)$, CAR: Carpentras $\left(5.03^{\circ} \mathrm{E}, 44.04^{\circ} \mathrm{N}\right)$, LIL: Lille $\left(3.08^{\circ} \mathrm{E}, 50.36^{\circ} \mathrm{N}\right)$, GOT: Gotland $\left(18.57^{\circ} \mathrm{E}, 57.55^{\circ} \mathrm{N}\right)$, LEI: IFT Leipzig $\left(12.26^{\circ} \mathrm{E}, 51.21^{\circ} \mathrm{N}\right)$ 
Table 2

List of EMEP and AirBase stations.

\begin{tabular}{llcl}
\hline Station & Latitude $\left({ }^{\circ} \mathrm{N}\right)$ & Longitude $\left({ }^{\circ} \mathrm{E}\right)$ & Country \\
\hline NL09(EP $\left.{ }^{\mathrm{a}}\right)$ & 53.20 & 6.17 & The Netherlands \\
NL10(EP) & 51.32 & 5.51 & The Netherlands \\
DERP017(AB $\left.{ }^{\mathrm{b}}\right)$ & 49.27 & 7.83 & Germany \\
DEUB002(AB) & 49.76 & 7.05 & Germany \\
DEUB005(AB) & 52.80 & 10.76 & Germany \\
FR10014(AB) & 50.98 & 2.14 & France \\
FR35006(AB) & 45.26 & 1.76 & France \\
ES08(EP) & 43.26 & -4.51 & Spain \\
ES10(EP) & 42.19 & -3.19 & Spain \\
ES0013R(AB) & 41.24 & -5.90 & Spain \\
ES0016R(AB) & 42.64 & -7.71 & Spain \\
ES1599A(AB) & 43.25 & -2.16 & Spain \\
ES1614A(AB) & 40.38 & -4.20 & Spain \\
GB0036R(AB) & 51.57 & -1.33 & United Kingdom \\
HU02(EP) & 46.58 & 19.35 & Hungary \\
IT01(EP) & 42.03 & 12.38 & Italy \\
PL02(EP) & 51.49 & 21.59 & Poland \\
PL04(EP) & 54.45 & 17.32 & Poland \\
SE0011R(AB) & 56.03 & 13.15 & Sweden \\
SK05(EP) & 49.22 & 19.41 & Slovakia \\
SK06(EP) & 49.03 & 22.16 & Slovakia \\
SK07(EP) & 47.58 & 17.52 & Slovakia \\
\hline
\end{tabular}

a EP: EMEP station.

b AB: AirBase station.

where $n 1$ and $n 2$ are the numbers of AERONET SSA data on the observational sites corresponding to AERONET AOT(440 nm) respectively above and less or equal to 0.2 .

The AERONET asymmetry parameter data product is retrieved with a $\pm 5 \%$ uncertainty (at the four wavelengths) (Dubovik and King, 2000).

For the year 2003, level 2.0 and 1.5 (when level 2.0 was not available) AERONET data from 13 European sites located as well close to as far from aerosol sources are considered (Fig. 1).

\subsection{MODIS aerosol optical thickness products}

To obtain larger spatial information on AOT, aerosol measurements by MODIS sensor are used in this work.
MODIS is a spectroradiometer taken on board of the TERRA and AQUA platforms. The operational algorithm derives aerosol optical thickness at $550 \mathrm{~nm}$ at $10 \mathrm{~km}$ resolution with a local overpass time around 11:00 a.m. over Europe. A cloud mask is used to determine cloud cover above the area of measurement. The MODIS cloud mask algorithm classifies pixels as either confident clear, probably clear, probably cloudy or cloudy. This pixel categorization is the result of tests applied to 20 of the 36 MODIS spectral bands to identify the presence of clouds (including cirrus) in the instrument field-of-view (King et al., 2003). The complete description of MODIS remote sensing of aerosol properties over land is described by Kaufman et al. (1997). In this study, we use collection C005 AOT data (cloud free) at $550 \mathrm{~nm}$ from the MODIS AQUA sensor. Uncertainty above continents is given by $0.05+0.2 \times$ AOT (Kaufman et al., 1997).

\section{Results and discussion}

In section 4.1, we evaluate the aerosol chemical module for the year 2003 on a seasonal basis using daily mean data of EMEP and AirBase observational sites. Then, a general evaluation of CHIMERE performances in simulating AOT, SSA and $g$ using AERONET and satellite inversions is discussed in Section 4.2. Finally in section 4.3, the aerosol module is evaluated for a typical episode of ammonium nitrate occurring on 27 March 2003 over northern France, Benelux and western Germany.

\subsection{PM observations versus modeling results}

We present here an evaluation of the PM10 and PM2.5 concentrations and also an evaluation of the main particulate species simulated by CHIMERE such as nitrate, sulfate and ammonium. 11 AirBase (for PM10 and PM2.5 comparisons) and $11 \mathrm{EMEP}$ (for $\mathrm{H}_{2} \mathrm{SO}_{4}$, $\mathrm{HNO}_{3}$ and $\mathrm{NH}_{4}$ comparisons) background stations, listed in Table 2, were selected to evaluate the aerosol chemical module over various European countries. As air quality model performances evaluation over Europe is usually performed on a seasonal basis (Bessagnet et al., 2004; Honoré et al., 2008), hereafter, comparisons are made for 4 seasonal periods: winter (DJF) corresponding to December-February, spring (MAM) corresponding to March-May, summer (JJA) corresponding to June-August and fall (SON)

Table 3

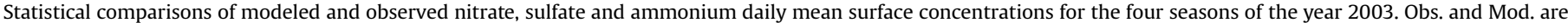

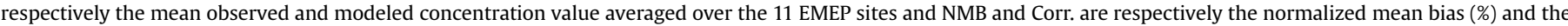
spatio-temporal correlation.

\begin{tabular}{|c|c|c|c|c|c|c|c|c|c|c|c|c|}
\hline & \multicolumn{4}{|c|}{ Nitrate } & \multicolumn{4}{|c|}{ Ammonium } & \multicolumn{4}{|c|}{ Sulfate } \\
\hline & DJF & MAM & JJA & SON & DJF & MAM & JJA & SON & DJF & MAM & JJA & SON \\
\hline Obs. $\left(\mu \mathrm{g} \mathrm{m}^{-3}\right)$ & 3.72 & 3.83 & 2.06 & 2.77 & 2.58 & 2.31 & 1.54 & 1.77 & 4.00 & 4.16 & 4.23 & 3.03 \\
\hline Mod. $\left(\mu \mathrm{g} \mathrm{m}^{-3}\right)$ & 6.98 & 6.17 & 0.48 & 4.84 & 3.96 & 3.66 & 1.52 & 3.28 & 3.90 & 4.21 & 4.09 & 3.71 \\
\hline Corr. & 0.54 & 0.72 & 0.46 & 0.66 & 0.49 & 0.66 & 0.57 & 0.69 & 0.60 & 0.56 & 0.38 & 0.56 \\
\hline NMB(\%) & 88 & 61 & -77 & 75 & 53 & 58 & -2 & 85 & -3 & 1 & -3 & 22 \\
\hline Ndata & 760 & 808 & 829 & 834 & 421 & 426 & 442 & 448 & 913 & 884 & 947 & 936 \\
\hline
\end{tabular}

Obs. $=\bar{O}=1 /$ Ndata $\sum_{i}^{\text {sites }} \sum_{j}^{\text {days }} O_{i, j}$

Mod. $=\bar{P}=1 /$ Ndata $\sum_{i}^{\text {sites }} \sum_{j}^{\text {days }} P_{i, j}$

$\operatorname{NMB}(\%)=100 /$ Ndata $\sum_{i}^{\text {sites }} \sum_{j}^{\text {days }}\left(P_{i, j}-O_{i, j}\right) / \sum_{i}^{\text {sites days }} \sum_{j} O_{i, j}$

Corr $=\frac{\sum_{i}^{\text {sites }} \sum_{j}^{\text {days }}\left(O_{i, j}-\bar{O}\right) \times\left(P_{i, j}-\bar{P}\right)}{\sqrt{\sum_{i}^{\text {sites }} \sum_{j}^{\text {days }}\left(O_{i, j}-\bar{O}\right)^{2}} \times \sqrt{\sum_{i}^{\text {sites }} \sum_{j}^{\text {days }}\left(P_{i, j}-\bar{P}\right)^{2}}}$

where $O_{i, j}$ and $P_{i, j}$ are respectively the observation and the model prediction at the site $i$ for the given day $j$. Ndata is the total number of samples. 
Table 4

Statistical comparisons of modeled and observed PM2.5 and PM10 surface concentrations for the four seasons of the year 2003. Obs., Mod. Corr. and NMB are calculated with equations (9)-(12) where sites represent the 11 AirBase sites.

\begin{tabular}{|c|c|c|c|c|c|c|c|c|}
\hline & \multicolumn{4}{|c|}{ PM2.5 } & \multicolumn{4}{|c|}{ PM10 } \\
\hline & DJF & MAM & JJA & SON & DJF & MAM & JJA & SON \\
\hline Obs. $\left(\mu \mathrm{g} \mathrm{m}^{-3}\right)$ & 12.2 & 13.6 & 12.9 & 10.2 & 17.5 & 21.6 & 23.3 & 18.1 \\
\hline Mod. $\left(\mu \mathrm{g} \mathrm{m}^{-3}\right)$ & 14.2 & 16.9 & 14.2 & 15.0 & 14.9 & 18.7 & 18.4 & 16.4 \\
\hline Corr. & 0.81 & 0.69 & 0.70 & 0.73 & 0.71 & 0.61 & 0.63 & 0.51 \\
\hline NMB(\%) & 16 & 25 & 10 & 46 & -15 & -13 & -21 & -10 \\
\hline Ndata & 581 & 595 & 548 & 575 & 924 & 948 & 918 & 916 \\
\hline
\end{tabular}

corresponding to September-November. Moreover, as comparisons between simulations and observations present low differences between each selected sites for a given season, statistical indicators used in this study (defined in Table 3) are calculated on a spatialaveraged basis over all the observational sites.

Results for nitrate, sulfate and ammonium surface concentrations for the four seasons of the year 2003 are presented in Table 3. Comparisons for the three species display spatio-temporal correlations in the range $0.38-0.72$ in accordance with current air quality models performances (Stern et al., 2008).

The CHIMERE model tends to overestimate nitrate and ammonium concentrations in winter, spring and fall with normalized mean bias (NMB) in the range $53-88 \%$ (cf Table 3 ). The artifacts in the measurements methods due to the volatilization of ammonium nitrate from filters during the conditioning procedure at $50^{\circ} \mathrm{C}$ could partly explain the model overestimation during these seasons (Favez et al., 2007). In summer, results for ammonium are quite good with small biases $(\mathrm{NMB}=-2 \%)$ whereas modeled nitrate concentrations are underestimated ( $\mathrm{NMB}=-77 \%)$. The non-negligible summer formation of nitrate by reaction of nitric acid on sea salt and soil dust (Lee et al., 2008) that is not implemented in CHIMERE could partly explain this model bias.

Performances of CHIMERE on sulfate are good with small biases $(-3 \% \leq \mathrm{NMB} \leq 22 \%)$ (cf Table 3$)$ for the four seasons. These results are encouraging since sulfur aqueous chemistry is difficult to simulate.
Table 4 displays statistical comparisons of modeled and observed PM2.5 and PM10 surface concentrations spatial-averaged over 11 Airbase sites (cf Table 2) for the four seasons of the year 2003. For PM2.5 and PM10, the spatio-temporal correlation coefficients are fairly good with values in the range $0.51-0.81$. In fall, winter and spring, the overestimation of PM2.5 $(\mathrm{NMB}=16-46 \%)$ are mainly caused by the overestimation of the inorganic fraction (especially nitrate and ammonium) principally found in the accumulation mode during these seasons. During summer, observed PM2.5 surface concentrations are rather well estimated by CHIMERE with small positive biases $(\mathrm{NMB}=10 \%)$.

Concerning PM10 surface concentrations, results give the small negative biases for the four seasons $(-21 \% \leq \mathrm{NMB} \leq-10 \%$, cf Table 4) in accordance with current chemistry transport model performances Honoré et al. (2008). Error compensations between aerosol chemical components are certainly responsible for a part of these good results (Seigneur, 2001). Indeed, the lack of resuspended coarse particles and mineral dust in the CHIMERE model could in partly be offset by the overestimated PM2.5 concentrations over the year 2003.

\subsection{General evaluation of the CHIMERE optical module}

To evaluate uncertainties on modeled aerosol optical properties, two sensitivity tests have been performed. The first one concerns the value of the complex refractive index of black carbon, which is the main absorbing aerosol species. Simulations have been performed by using the $\mathrm{BC}$ refractive index values of $1.75-\mathrm{i} 0.44$ (Hess et al., 1998) and 1.95-i0.66 (Bergström, 1972). Estimates of simulated optical properties are then compared with those obtained with the reference value of 1.87-i0.569 (Marley et al., 2001) used thereafter in our simulations. Moreover, in the absence of extensive validation of $\mathrm{BC}$ mass concentrations simulated by CHIMERE, we evaluated, in a second approach, the impact of an increase/decrease of $20 \%$ of simulated BC mass concentration on modeled optical properties. These two types of sensitivity tests indicate, for the three aerosol mixings, small discrepancies equal to:
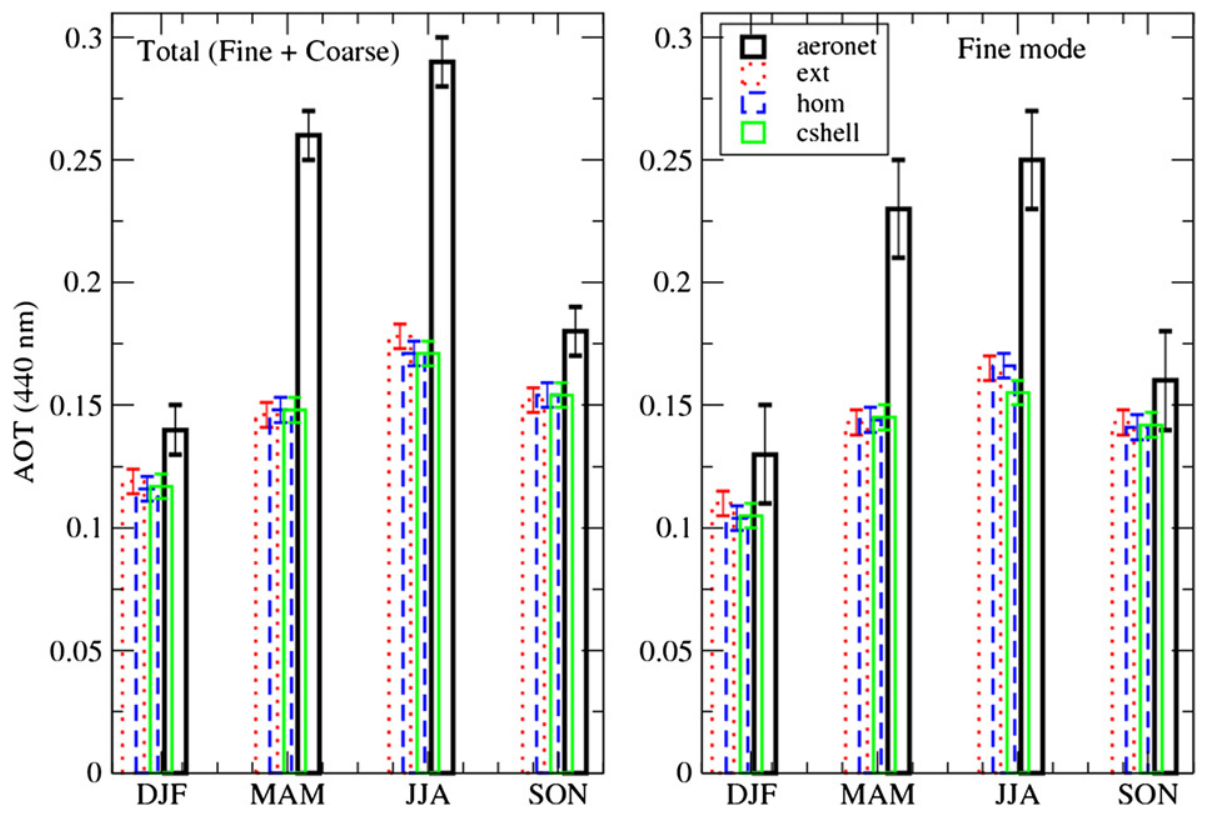

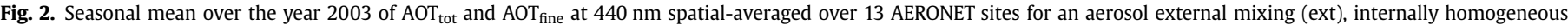

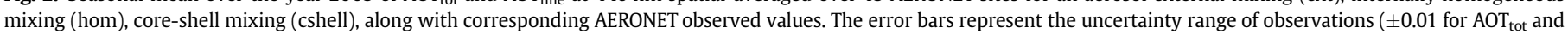
\pm 0.02 for $\mathrm{AOT}_{\text {fine, }}$ see Holben et al., 2001; Dubovik, 2010) and simulations ( \pm 0.005 for $\mathrm{AOT}_{\text {tot }}$ and $\mathrm{AOT}_{\text {fine }}$ for the three mixings; see sensitivity tests described in Section 4.2 ). 
Table 5a

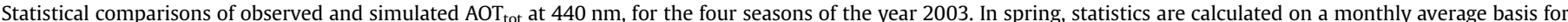

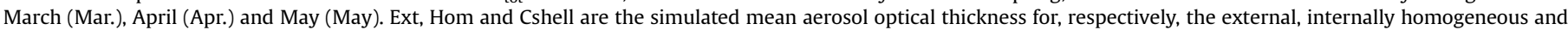
core-shell aerosol mixing. Obs., ext, hom, cshell, Corr. and NMB are calculated with equations (9)-(12) where sites represent the 13 AERONET stations.

\begin{tabular}{|c|c|c|c|c|c|c|}
\hline & \multicolumn{6}{|l|}{$\mathrm{AOT}_{\text {tot }}$} \\
\hline & DJF & Mar. & Apr. & May & JJA & SON \\
\hline Obs. & $0.14 \pm 0.01$ & $0.26 \pm 0.01$ & $0.29 \pm 0.01$ & $0.24 \pm 0.01$ & $0.29 \pm 0.01$ & $0.18 \pm 0.01$ \\
\hline Ext & $0.119 \pm 0.005$ & $0.199 \pm 0.005$ & $0.127 \pm 0.005$ & $0.112 \pm 0.005$ & $0.178 \pm 0.005$ & $0.152 \pm 0.005$ \\
\hline NMB (\%) & -17 & -23 & -56 & -53 & -48 & -21 \\
\hline Corr. & 0.67 & 0.63 & 0.74 & 0.63 & 0.65 & 0.55 \\
\hline Hom & $0.116 \pm 0.005$ & $0.206 \pm 0.005$ & $0.130 \pm 0.005$ & $0.109 \pm 0.005$ & $0.171 \pm 0.005$ & $0.154 \pm 0.005$ \\
\hline NMB (\%) & -20 & -21 & -55 & -54 & -54 & -18 \\
\hline Corr. & 0.62 & 0.60 & 0.73 & 0.53 & 0.62 & 0.51 \\
\hline Cshell & $0.117 \pm 0.005$ & $0.206 \pm 0.005$ & $0.130 \pm 0.005$ & $0.109 \pm 0.005$ & $0.171 \pm 0.005$ & $0.154 \pm 0.005$ \\
\hline NMB (\%) & -17 & -21 & -55 & -54 & -53 & -18 \\
\hline Corr. & 0.62 & 0.59 & 0.73 & 0.53 & 0.62 & 0.50 \\
\hline Ndata & 435 & 320 & 310 & 257 & 1506 & 832 \\
\hline
\end{tabular}

\pm 0.005 on modeled $\mathrm{AOT}_{\text {tot }}$ and $\mathrm{AOT}_{\text {fine }}$

\pm 0.001 on simulated asymmetry parameter.

Concerning the modeled single scattering albedo, discrepancies are larger and equal to \pm 0.03 for the external and core-shell mixing and \pm 0.04 for the internally homogeneous one.

\subsubsection{Aerosol optical thickness}

Fig. 2 shows the seasonal mean values of the observed and simulated AOT (at $440 \mathrm{~nm}$ ) for the total and fine aerosol size distribution averaged over the 13 AERONET sites. Uncertainties are indicated with error bars. Tables $5 \mathrm{a}$ and $5 \mathrm{~b}$ present corresponding error statistics (In spring, statistics are calculated on a monthly average basis for March, April and May 2003). In Fig. 2, we can see that differences on modeled AOT values between the three aerosol mixings are small (with discrepancies less than $10 \%$ ), which is coherent with previous studies showing low impact of the aerosol mixing on modeled extinction (Fassi-Fihri et al., 1997; Tombette et al., 2008). A clear seasonal cycle is observed and is rather well reproduced by CHIMERE although simulations indicate a much weaker seasonal variation. AERONET AOT values are the lowest during winter $\left(\mathrm{AOT}_{\text {tot }}=0.14 \pm 0.01\right)$ and the highest during summer $2003\left(\mathrm{AOT}_{\text {tot }}=0.29 \pm 0.01\right.$ ), characterized by stable atmospheric conditions over Europe favorable to the accumulation of particulate pollution (Vautard et al., 2007). The model seems to well reproduce the variability of observations in both space and time with spatiotemporal correlation in the range $0.50-0.74$.
In winter and fall, modeled $\mathrm{AOT}_{\text {tot }}$ and $\mathrm{AOT}_{\text {fine }}$ (for aerosol radius $\leq 0.6 \mu \mathrm{m}$ ) values agree well with AERONET observations with small negative biases $(-21 \% \leq \mathrm{NMB} \leq-16 \%$, cf Tables $5 \mathrm{a}$ and $\mathrm{b})$, which could indicate a rather good estimation of vertically integrated particles loading in spite of overestimated PM2.5 surface concentrations during these seasons.

In early spring (March 2003), AERONET AOT rather well estimated by CHIMERE $(-23 \% \leq \mathrm{NMB} \leq-21 \%$, cf Tables $5 \mathrm{a}$ and $5 \mathrm{~b}$ ) for particulate pollution dominated by secondary inorganic aerosols. In that sense, an ammonium nitrate episode that occurred over northern France and western Germany during March 2003 will be further investigated in section 4.3.

In late spring (April-May 2003) and summer, large discrepancies between AERONET and CHIMERE $\mathrm{AOT}_{\text {tot }}$ and $\mathrm{AOT}_{\text {fine }}(-56 \% \leq$ $\mathrm{NMB} \leq-43 \%$, cf Tables $5 \mathrm{a}$ and $5 \mathrm{~b}$ ) could be related to uncertainties in accurately modeling secondary aerosol species.

\subsubsection{Single scattering albedo and asymmetry parameter}

Studying single scattering albedo and asymmetry parameter is of particular interest when evaluating an aerosol model as they strongly depend on particle size, chemical composition and degree of mixing.

As shown by Chubarova (2009), SSA and $g$ do not present a seasonal variation over Europe as pollution is mainly dominated by fine urban/industrial and biomass burning aerosols over the year. Hence, hereafter comparisons between model and observations are made on an annual average basis.

Table 5b

The same as Table $5 \mathrm{a}$ but for $\mathrm{AOT}_{\text {fine }}$

\begin{tabular}{|c|c|c|c|c|c|c|}
\hline & \multicolumn{6}{|l|}{$\mathrm{AOT}_{\text {fine }}$} \\
\hline & DJF & Mar. & Apr. & May & JJA & SON \\
\hline Obs. & $0.13 \pm 0.02$ & $0.25 \pm 0.02$ & $0.25 \pm 0.02$ & $0.20 \pm 0.02$ & $0.25 \pm 0.02$ & $0.16 \pm 0.02$ \\
\hline Ext & $0.110 \pm 0.005$ & $0.197 \pm 0.005$ & $0.123 \pm 0.005$ & $0.110 \pm 0.005$ & $0.165 \pm 0.005$ & $0.143 \pm 0.005$ \\
\hline NMB (\%) & -16 & -23 & -51 & -44 & -45 & -18 \\
\hline Corr. & 0.67 & 0.67 & 0.73 & 0.57 & 0.59 & 0.63 \\
\hline Hom & $0.104 \pm 0.005$ & $0.202 \pm 0.005$ & $0.126 \pm 0.005$ & $0.105 \pm 0.005$ & $0.166 \pm 0.005$ & $0.141 \pm 0.005$ \\
\hline NMB (\%) & -20 & -21 & -50 & -46 & -43 & -19 \\
\hline Corr. & 0.65 & 0.64 & 0.72 & 0.52 & 0.59 & 0.58 \\
\hline Cshell & $0.105 \pm 0.005$ & $0.202 \pm 0.005$ & $0.127 \pm 0.005$ & $0.106 \pm 0.005$ & $0.155 \pm 0.005$ & $0.142 \pm 0.005$ \\
\hline NMB (\%) & -19 & -21 & -49 & -46 & -49 & -18 \\
\hline Corr. & 0.62 & 0.63 & 0.72 & 0.52 & 0.59 & 0.57 \\
\hline Ndata & 665 & 488 & 564 & 662 & 3099 & 1550 \\
\hline
\end{tabular}



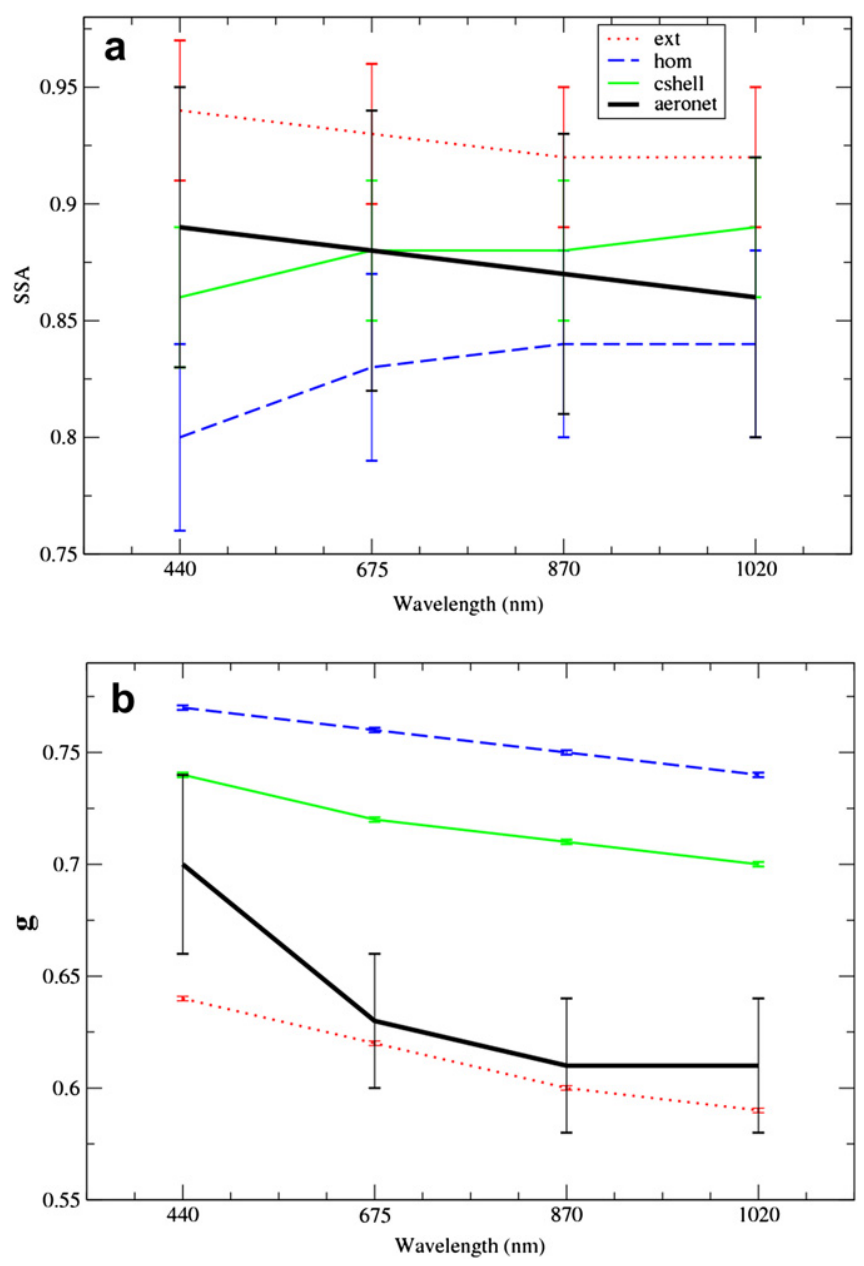

Fig. 3. Wavelength dependence of the annual mean SSA (a) and g (b) simulated by CHIMERE for the three aerosol mixings along with AERONET observations spatialaveraged over the 13 observational sites for the year 2003. The error bars represent the uncertainty range of: (a) observed $( \pm 0.06$, calculated using equation (8)) and simulated ( \pm 0.03 for the external and core-shell mixing and \pm 0.04 for the internally homogeneous one) SSA. (b): observed ( $\pm 5 \%$, see Dubovik and King, 2000)) and simulated ( \pm 0.001 for the three mixings) $\mathrm{g}$.

Fig. 3 shows the wavelength dependence of the annual mean SSA (a) and $g$ (b) simulated by CHIMERE for the three aerosol mixings along with AERONET inversions spatial-averaged over the 13 observational sites for the year 2003. Corresponding uncertainties are also indicated.

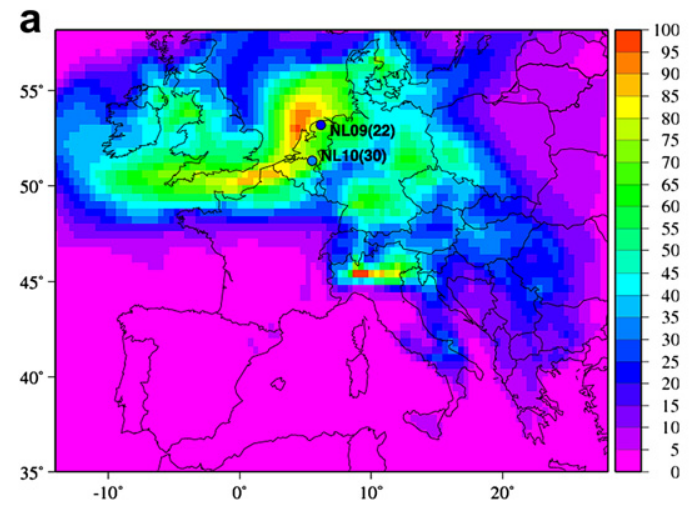

The annual mean observed SSA value (at $440 \mathrm{~nm}$ ) averaged over the domain is $0.89 \pm 0.06$ corresponding to moderate absorbing aerosol (Fig. 3a) and is close to the annual mean AERONET value of 0.93 observed over Europe in 2001 by Tombette et al. (2008).

AERONET SSA shows a low sensitivity to wavelengths with a slight decrease from $0.89 \pm 0.06$ at $440 \mathrm{~nm}$ to $0.86 \pm 0.06$ at $1020 \mathrm{~nm}$, which is consistent with results obtained for urban/industrial pollution in previous studies (Alados-Arboledas et al., 2008; Yu et al., 2009). Modeled SSA is fairly constant with increasing wavelength for the three aerosol mixings (Fig. 3a). At the opposite, it is very sensitive to the treatment of particles mixing. Indeed, the core-shell SSA exhibits close match at the annual mean $(0.86-0.89 \pm 0.03)$ with AERONET measured values $(0.86-0.89 \pm 0.06)$ compared to externally $(0.92-0.94 \pm 0.03)$ and internally homogeneous $(0.80-0.84 \pm 0.04)$ mixing, as shown in previous works by Péré et al. (2009).

Results for the asymmetry parameter are displayed in Fig. 3b. Values for the external treatment $(0.592 \pm 0.001 \leq g \leq 0.641 \pm 0.001)$ are lower than those obtained for the internally homogeneous $(0.740 \pm 0.001 \leq g \leq 0.771 \pm 0.001)$ and core-shell $(0.700 \pm 0.001 \leq$ $g \leq 0.739 \pm 0.001)$ suggesting a slightly larger proportion of modeled fine aerosols in the external treatment in the absence of coagulation between particles. Differences of values between the two internal mixing states are due to changes in the modeled complex refractive indexes (as the simulated aerosol size distribution is the same for both the two internal mixings). The AERONET values vary from $0.70 \pm 0.04$ at $440 \mathrm{~nm}$ to $0.61 \pm 0.03$ at $1020 \mathrm{~nm}$ with a noteworthy decrease in the wavelength range $440-675 \mathrm{~nm}$ (from $0.70 \pm 0.04$ to $0.63 \pm 0.03$ ) and small variation in the range $675-1020 \mathrm{~nm}(0.61 \pm 0.03 \leq g \leq 0.63$ \pm 0.03 ). Such a behavior has already been observed over Spain by Lyamani et al. $(2004,2006)$ and is characteristic of fine urban-industrial and biomass burning aerosols (Dubovik et al., 2001; Lyamani et al., 2006). Simulated g presents a less pronounced spectral dependence for the three aerosol mixings. However, discrepancies between observations and simulations (for the three mixings) remain small at the four wavelengths with up to 10-15\% differences. Therefore, the hypothesis of an aerosol considered as a homogeneous sphere seems being here a rather good approximation to compute the asymmetry parameter of fine urban/industrial and biomass burning particles.

\subsection{March 2003: episode of ammonium nitrate}

In winter and spring, Western Europe can be affected by ammonium nitrate episodes when nitric acid is neutralized by ammonia (mainly of agricultural origin, Reis et al. (2009) to form ammonium nitrate in the particulate phase (Stern et al., 2008). To illustrate this situation, the case of 27 March 2003 is selected. Observed concentrations of ammonium nitrate for this day are in the range $22-30 \mu \mathrm{g} \mathrm{m}^{-3}$ over the Netherlands (cf Fig. 4a), which is

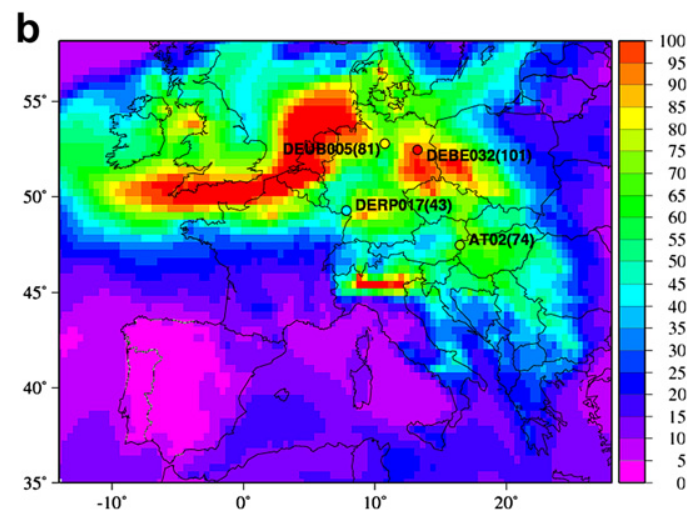

Fig. 4. Predicted daily mean ground concentrations of (a) ammonium nitrate and (b) PM10 ( $\mu \mathrm{g} \mathrm{m}^{-3}$ ) on 27 March 2003 with corresponding mean observed values (circles). 
a CHIMERE AOT tot $(440 \mathrm{~nm})$ with AERONET values

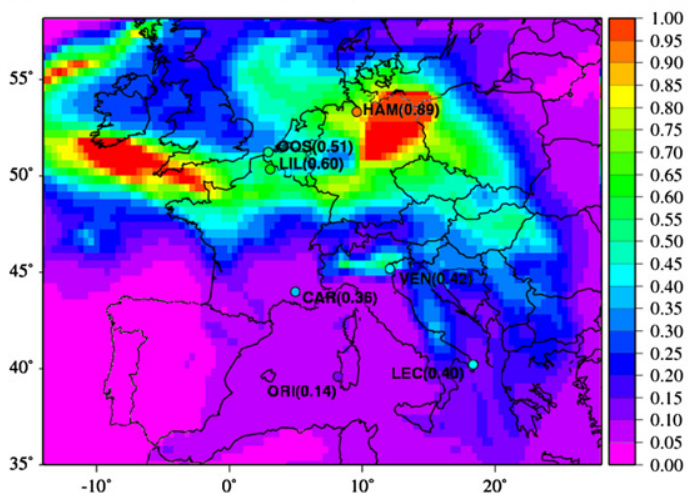

b

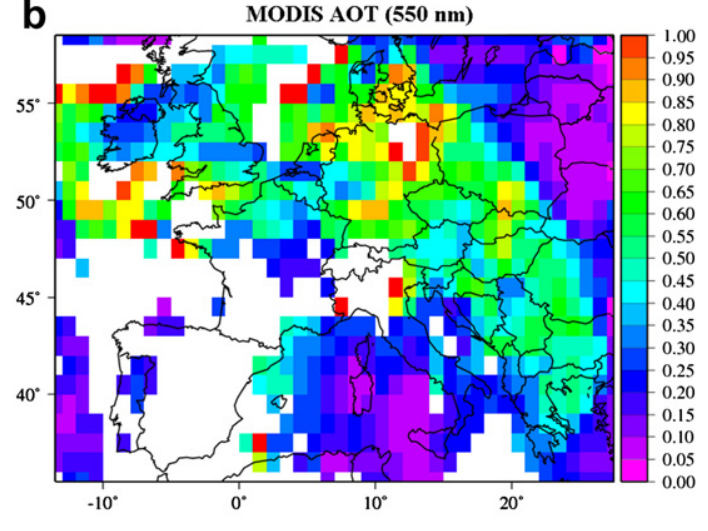

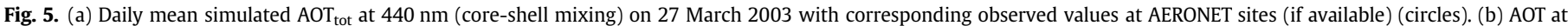
$550 \mathrm{~nm}$ retrieved by the MODIS sensor.

about twice higher than normally observed at this time over this region (Zee et al., 1998). Model results show concentrations in the range $40-60 \mu \mathrm{g} \mathrm{m}^{-3}$ over northern France, Benelux and a large part of Germany. Such levels are overestimated over the Netherlands by a factor of 2-2.5 as compared to EMEP measurements. However, PM10 concentrations are fairly well reproduced with $\pm 20 \%$ differences compared to AirBase observations (Fig. 4b). This could be partly due to error compensations between aerosol chemical components (Seigneur, 2001).

The optical signature of the aerosol plume is very pronounced with simulated $\mathrm{AOT}_{\text {tot }}$ at $440 \mathrm{~nm}$ (core-shell mixing) in the range $0.5-1$ in rather good agreements with AERONET (Fig. 5a) and MODIS (Fig. 5b) observations. Moreover, AOT over the AERONET sites of Venise and Oristano are fairly well estimated by CHIMERE, while observed values over the sites of Carpentras and Lecce are clearly underestimated by the model.
The spectral variation of the observed AOT, spatial-averaged over the three AERONET sites located inside the aerosol plume (Lille, Oostende and Hamburg), is marked with a decrease from $0.68 \pm 0.01$ at $440 \mathrm{~nm}$ to $0.22 \pm 0.01$ at $1020 \mathrm{~nm}$ (Fig. 6a). Such a behavior is mainly due to the fine aerosol mode (Fig. 6b), which is well reproduced by the model for the three aerosol mixings. This indicates that CHIMERE is able to well reproduce the fine mode volume size distribution (Fig. 6c), with a simulated accumulation mode for the internal aerosol mixing (internally homogeneous and core-shell) in the range $\simeq 0.07-0.2 \mu \mathrm{m}$ fitting fairly well with AERONET retrievals (observed accumulation mode for radius about $0.1-0.2 \mu \mathrm{m}$ ) (cf Fig. 6c). However, the external aerosol mixing displays a much broader accumulation mode with a higher volume concentration of very fine particles (for radius in the range $0.03-0.06 \mu \mathrm{m}$ ). The modeled fine mode volume concentration (for the internal and external treatments) is much lower than the observed one, which leads to slightly underestimated values of $\mathrm{AOT}_{\text {fine }}$
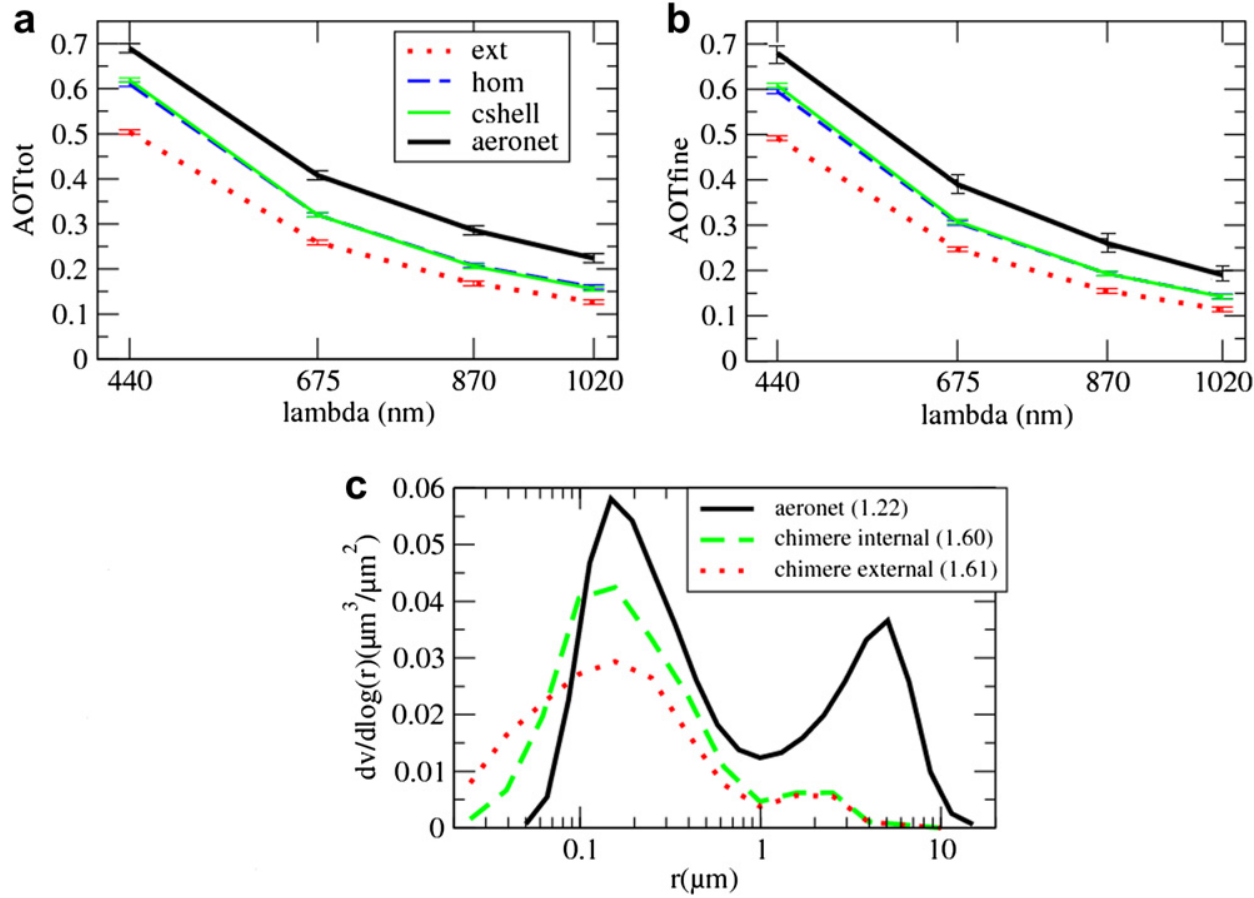

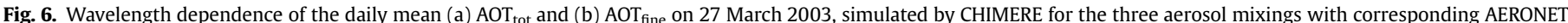

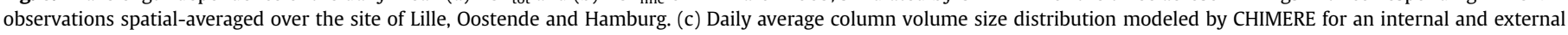
aerosol treatment and retrieved by AERONET with corresponding daily mean values of the Angström exponent. 


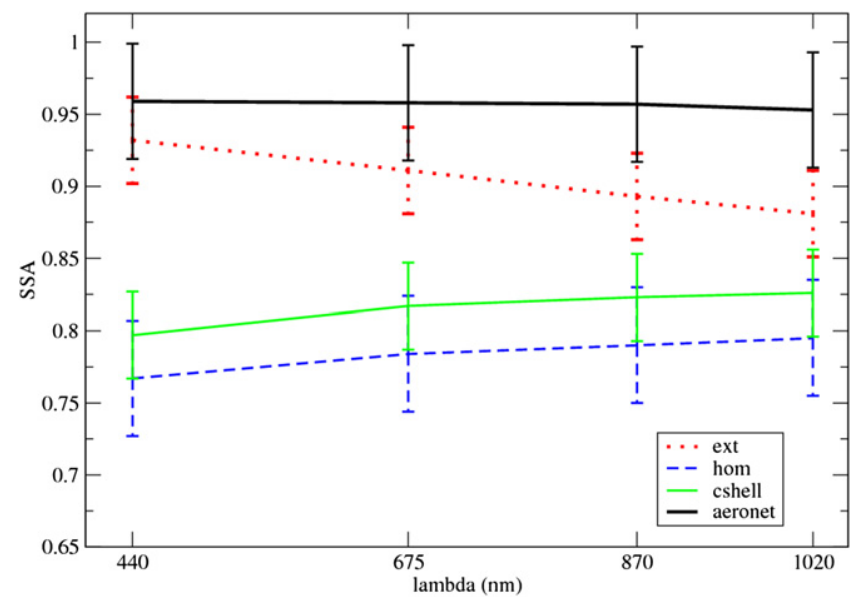

Fig. 7. Wavelength dependence of the daily mean SSA on 27 March 2003 simulated by CHIMERE for the three aerosol mixings along with corresponding AERONET observations spatial-averaged over the site of Lille, Oostende and Hamburg.

for the three aerosol mixings. In parallel, underestimated emissions of primary wind blown particles in CHIMERE lead to an almost nonexistent modeled coarse mode volume concentration (radius $\simeq 1-3 \mu \mathrm{m}$ ) as compared to AERONET retrievals (observed coarse mode for radius $\simeq 3-7 \mu \mathrm{m}$ ). This induces a higher modeled Angström exponent value $\left(\alpha_{\text {model }}(440-870 \mathrm{~nm})=1.60\right.$ (internally homogeneous and core-shell mixing) and 1.61 (external mixing)) compared to the AERONET one $\left(\alpha_{\text {aeronet }}(440-870 \mathrm{~nm})=1.22\right)$ (cf Fig. 6c).

The low absorbing properties of the aerosol plume dominated by ammonium nitrate are observed with a mean high AERONET SSA (at $440 \mathrm{~nm}$ ), spatial-averaged over the three stations of Lille, Oostende and Hamburg, equal to $0.96 \pm 0.04$ (Fig. 7). This is in agreement with the value of $0.93 \pm 0.04$ calculated over Southern France for water soluble nitrate particles by Mallet et al. (2003). Fig. 7 shows that SSA ext $(0.88-0.93 \pm 0.03)$ matches better with the observations $(0.95-0.96 \pm$ $0.03)$ for the four wavelengths than $\mathrm{SSA}_{\text {hom }}(0.77-0.80 \pm 0.04)$ and $\mathrm{SSA}_{\text {cshell }}(0.80-0.83 \pm 0.03)$, which is different than results reported in section 4.2.2 showing that annual mean $\mathrm{SSA}_{\text {cshell }}(0.86 \pm 0.03$ at $440 \mathrm{~nm})$ agrees well with observations $(0.89 \pm 0.04)$ compared to external $(0.94 \pm 0.03)$ and internally homogeneous $(0.80 \pm 0.04)$ mixings. In this case, increase of the particle water uptake by high concentrations of hydrophilic ammonium nitrate aerosols could reinforce the refraction of light from the aerosol shell into the aerosol BC core, resulting in a enhancement of the particle absorption (Moffet and Prather, 2009). This could lead to an underestimation of the observed SSA by the core-shell approach. Fuller et al. (1999) also indicate that the core-shell treatment may overestimate aerosol light absorption by less than $15 \%$ in comparison to the random location of soot agglomerates, due to the focusing of electromagnetic energy at the $\mathrm{BC}$ core by lensing (Redemann et al., 2001).

\section{Conclusions}

The objective of this study was to develop an aerosol optical scheme in the chemistry transport model CHIMERE, allowing to use AERONET and satellite retrievals as a complement to EMEP and Airbase database to evaluate performance of the model. Comparisons between simulations and observations were made over Western Europe for the year 2003 but also for one specific case focused on ammonium nitrate aerosols.

Results of simulations conducted for the year 2003 indicated that the seasonal cycle of modeled AOT (few sensitive to particle mixing) agreed well with AERONET observations (correlations in the range $0.50-0.74)$. However, modeling results revealed also some biases according to seasons. In fall, winter and early spring, $\mathrm{AOT}_{\text {tot }}$ and $\mathrm{AOT}_{\text {fine }} \mathrm{AERONET}$ values are well reproduced by the model with small negative biases. Results obtained for a pollution episode of ammonium nitrate (March 2003) revealed that the CHIMERE model rather well estimated AERONET fine mode volume size distribution, leading to good agreements between modeled and observed AOT. In parallel, the overestimation of hydrophilic ammonium nitrate concentrations during this episode led to important discrepancies between AERONET and core-shell SSA, due to the thickness of the aerosol shell.

In late spring and summer, uncertainties in modeling secondary aerosol species could explain the underestimation of AOT during this period.

This study clearly showed the great interest to simulate aerosol optical and microphysical properties directly comparable with AERONET and satellite observations for testing/evaluating air quality modeling exercises. Future works using this optical module will be conducted for investigating other aerosol regimes, such as biomass burning particles. Furthermore, this new optical scheme will be used to investigate effects of brown carbon particles (including all light absorbing carbonaceous species) on ultraviolet radiations and possible feedbacks on regional photochemistry and ozone production.

\section{Acknowledgements}

We would like to thank the Principal Investigators of the AERONET sites used in this study. We are also grateful to Jean-François Léon at Laboratoire d'Aérologie (Toulouse) and MODIS mission scientists and associated NASA personnel for providing satellite imageries. We would also like to acknowledge H. Chepfer, L. Menut and S. Turquety at IPSL, LMD, CNRS for their scientific support.

\section{References}

Adachi, K., Buseck, P.R., 2008. Internally mixed soot, sulfates, and organic matter in aerosol particles from Mexico City. Atmospheric Chemistry and Physics 8, 6469-6481.

Adams, M., Barrett, K., van het Bolscher, M., Larssen, S., de Leeuw, F., Pulles, T., van Loon, M., van Pul, A., Swart, R., 2007. Air pollution in Europe 1990-2004. European Environment Agency report.

Alados-Arboledas, L., Alcantara, A., Olmo, F.J., Martinez-Lozano, J.A., Estelles, V., Cachorro, V., Silva, A.M., Horvath, H., Gangl, M., Diaz, A., Pujadas, M., Lorente, J., Labajo, A., Sorribas, M., Pavese, G., 2008. Aerosol columnar properties retrieved from CIMEL radiometers during VELETA 2002. Atmospheric Environment 42, 2654-2667.

Barrett, K., de Leeuw, F., Fiala, J., Larssen, S., Sundvor, I., Fjellsbo, L., Dusinska, M., Ostatnicka, J., Horallek, J., Cernikovsky, L., Barmpas, F., Moussipoulos, N., Vlahocostas, C., 2008. Health impacts and air pollution. An exploration of factors influencing estimates of air pollution impact upon the health of European citizens. ETC/ACC Technical paper 2008/13. European Topic Centre on Air and Climate Change.

Bergström, R.W., 1972. Predictions of the spectral absorption and extinction coefficients of an urban air pollution model. Atmospheric Environment 6, 247-258.

Bessagnet, B., Hodzic, A., Vautard, R., Beekmann, M., Cheinet, S., Honoré, C., Liousse, C., Rouil, L., 2004. Aerosol modeling with CHIMERE-preliminary evaluation at the continental scale. Atmospheric Environment 38, 2803-2817.

Bessagnet, B., Menut, L., Curci, G., Hodzic, A., Guillaume, B., Liousse, C., Moukhtar, S., Pun, B., Seigneur, C., Schulz, M., 2009. Regional modeling of carbonaceous aerosols over Europe-Focus on secondary organic aerosols. Journal of Atmospheric Chemistry 61, 175-202.

Chubarova, N.Y., 2009. Seasonal distribution of aerosol properties over Europe and their impact on UV irradiance. Atmospheric Measurement Techniques 2, 593-608.

d'Almeida, G.A., Koepke, P., Shettle, E.P., 1991. Atmospheric Aerosols - Global Climatology and Radiative Characteristics. Hampton, Virginia.

Dey, S., Tripathi, S.N., Mishra, S.K., 2008. Probable mixing state of aerosols in the Indo-Gangetic Basin, northern India. Geophysical Research Letters 35, L03808. doi:10.1029/2007GL032622.

Dubovik, O., 2010. Personal communication. January.

Dubovik, O., Holben, B., Eck, T.F., Smirnov, A., Kaufman, Y.., King, M.D., Tanré, D. Slutsker, I., 2001. Variability of absorption and optical properties of key aerosol types observed in worldwide locations. Journal of the Atmospheric Sciences 59, 590-608. 
Dubovik, O., King, M.D., 2000. A flexible inversion algorithm for retrieval of aerosol optical properties from sun and sky radiance measurements. Journal of Geophysical Research 105, 20673-20696.

Dubovik, O., Smirnov, A., Holben, B., King, M., Kaufman, Y., Eck, T., Slutsker, I., 2000. Accuracy assessments of aerosol optical properties retrieved from aerosol robotic network (aeronet) sun and sky radiance measurements. Journal of Geophysical Research 105, 9791-9806.

Dudhia, J., 1993. A nonhydrostatic version of the Penn State NCAR mesoscale model: validation tests and simulation of an Atlantic cyclone and cold front. Monitoring Weather Review 121, 1493-1513.

Engel-Cox, J.A., Holloman, C.H., Coutant, B.W., Hoff, R.M., 2004. Qualitative and quantitative evaluation of MODIS satellite sensor data for regional and urban scale air quality. Atmospheric Environment 38, 2495-2509.

Fassi-Fihri, A., Suhre, K., Rosset, R., 1997. Internal and external mixing in atmospheric aerosols by coagulation: impact on the optical and hygroscopic properties of the sulfate-soot system. Atmospheric Environment 31, 1393-1402.

Favez, O., Cachier, H., Sciare, J., Moullec, Y.L., 2007. Characterization and contribution to PM2.5 of semi-volatile aerosols in Paris (France). Atmospheric Environment 41, 7969-7976.

Fuller, K.A., Malm, W.C., Kreidenweis, S.M., 1999. Effects of mixing on extinction by carbonaceous particles. Journal of Geophysical Research 104, 941-954.

Garland, R.M., Yang, H., Schmid, O., Rose, D., Gunthe, S.S., 2009. Aerosol optical properties in the mega-cities Beijing and Guangzhou: measurements and implications for regional air pollution, aerosol sources and remote sensing. Geophysical Research Abstracts.

Gelencser, A., May, B., Simpson, D., Sanchez-Ochoa, A., Kasper-Giebl, A. Puxbaum, H., Caseiro, A., Pio, C., Legrand, M., 2007. Source apportionment of PM2.5 organic aerosol over Europe: primary/secondary, natural/anthropogenic and fossil/biogenic origin. Journal of Geophysical Research 112, D23S04. doi:10.1029/2006JD008094.

Guenther, A., Karl, T., Harley, P., Wiedinmyer, C., Palmer, P.I., Geron, C., 2006. Estimates of global terrestrial isoprene emissions using MEGAN (Model of Emissions of Gases and Aerosols from Nature). Atmospheric Chemistry and Physics 6, 3181-3210.

Gyawali, M., Arnott, W.P., Lewis, K., Moonsmüller, H., 2009. In situ aerosol optics in Reno, NV, USA during and after the summer 2008 California wildfires and the influence of absorbing and non-absorbing organic coatings on spectral light absorption. Atmospheric Chemistry and Physics 9, 8007-8015.

Hallquist, M., Wenger, J.C., Baltensperger, U., Rudich, Y., Simpson, D., Claeys, M., Dommen, J., Donahue, N.M., George, C., Goldstein, A.H., Hamilton, J.F. Herrmann, H., Hoffmann, T., Iinuma, Y., Jang, M., Jenkin, M.E., Jimenez, J.L., Kiendler-Scharr, A., Maenhaut, W., McFiggans, G., Mentel, T.F., Monod, A., Seinfeld, J.H., Surratt, J.D., Szmigielski, R., Wildt, J., 2009. The formation, properties and impact of secondary organic aerosol: current and emerging issues. Atmospheric Chemistry and Physics 9, 5155-5236.

Hess, M., Koepke, P., Schult, I., 1998. Optical properties of aerosols and clouds: the software package OPAC. Bulletin of the American Meteorological Society 79 831-844.

Hodzic, A., Madronich, S., Bohn, B., Massie, S., Menut, L., Wiedinmyer, C., 2007. Wildfire particulate matter in Europe during summer 2003: meso-scale modeling of smoke emissions, transport and radiative effects. Atmospheric Chemistry and Physics 7, 4043-4064.

Holben, B.N., Tanré, D., Smirnov, A., Eck, T.K., Slutsker, I., Abuhassan, N., Newcomb, W.W., Schafer, J.S., Chatenet, B., Lavenu, F., Kaufman, Y.J., Castle, J.V., Setzer, A., Markham, B., Clarck, D., Frouin, R., Halthore, R., Kameli, A., O'Neil, N.T., Pietras, C., Pinker, R.T., Vass, K., Zibordi, G., 2001. An emerging ground-based aerosol climatology: Aerosol optical depth from AERONET. Journal of Geophysical Research 106, 12067-12097.

Höller, R., Kasahara, M., Tohno, S., Horvath, H., 2000. Aerosol single-scattering albedo and its relation to black carbon concentration at urban and coastal locations in Japan. Journal of Aerosol Science 31, 646-647.

Honoré, C., Rouil, L., Vautard, R., Beekmann, M., Bessagnet, B., Dufour, A Elichegaray, C., Flaud, J.M., Malherbe, L., Meleux, F., Menut, L., Martin, D., Peuch, A., Peuch, V.H., Poisson, N., 2008. Predictability of European air quality: assessment of 3 years of operational forecasts and analyses by the PREV'AIR system. Journal of Geophysical Research 113, D04301. doi:10.1029/2007JD008761.

Horvath, H., 1993. Atmospheric light absorption - a review. Atmospheric Environment 27A, 293-317.

Jacobson, M., 2000. A physically-based treatment of elemental carbon optics: implications for global direct forcing of aerosols. Geophysical Research Letters 27, 217-220.

Junker, C., Liousse, C., 2008. A global emission inventory of carbonaceous aerosol from historic record of fossil fuel and biofuel consumption for the period 1860-1997. Atmospheric Chemistry and Physics 8, 1195-1207.

Kaufman, Y.J., Tanré, D., Remer, L., Vermote, E., Chu, A., Holben, B.N., 1997. Operational remote sensing of tropospheric aerosol over the land from EOS-MODIS. Journal of Geophysical Research 102, 17051-17068.

Khalizov, A.F., Zhang, R., Zhang, D., Xue, H., Pagels, J., McMurry, P.H., 2009. Formation of highly hygroscopic soot aerosols upon internal mixing with sulfuric acid vapor. Journal of Geophysical Research 114, D05208.

King, M.D., Menzel, W.P., Kaufman, Y.J., Tanré, D., Gao, B.C., Platnick, S., Ackerman, S. A., Remer, L.A., Pincus, R., Hubanks, P.A., 2003. Cloud and aerosol properties, precipitable water, and profiles of temperature and humidity from MODIS. IEEE Transactions on Geoscience and Remote Sensing 41, 442-458.

Krekov, G.M., 1993. Aerosols Effects on Climate. University of Arizona press, Tucson, AZ.
Lee, T., Yu, X.Y., Ayres, B., Kreidenweiss, S.M., Malm, W.C., Collet, J.L., 2008. Observations of fine and coarse particle nitrate at several rural locations in the United States. Atmospheric Environment 42, 2720-2732.

Lesins, G., Chylek, P., Lohmann, U., 2002. A study of internal and external mixing scenarios and its effect on aerosol optical properties and direct radiative forcing. Journal of Geophysical Research 107, 4094.

Lyamani, H., Olmo, F.J., Alados-Arboledas, L., 2004. Long-term changes in aeroso radiative properties at Armilla (Spain). Atmospheric Environment 38, 5935-5943.

Lyamani, $\mathrm{H}$, Olmo, FJ. Alcantara, A Alados-Arboledas, L, 2006. Atmospheric aerosols during the 2003 heat wave in southeastern Spain amalg: microphysica columnar properties and radiative forcing. Atmospheric Environment 40, 6465-6476.

Mallet, M., Roger, J., Despiau, S., Dubovik, O., Putaud, J., 2003. Microphysical and optical properties of aerosol particles in urban zone during ESCOMPTE. Atmospheric Research 69, 73-97.

Mallet, M., Roger, J.C., Despiau, S., Putaud, J.P., Dubovik, O., 2004. A study of the mixing state of black carbon in urban zone. Journal of Geophysical Research 109. doi:10.1029/2003JD003940.

Mallet, V., Quélo, D., Sportisse, B., de Biasi, M.A., Debry, E., Korsakissov, I., Wu, L. Roustan, Y., Sartelet, K., Tombette, M., Foudhil, H., 2007. Technical note: the air quality modeling system Polyphemus. Atmospheric Chemistry and Physics 7.

Marley, N.A., Gaffney, J.S., Baird, J.C., Blazer, C.A., Drayton, P.J., Frederick, J.E., 2001. An empirical method for the determination of the complex refractive index of size-fractionated atmospheric aerosols for radiative transfert calculations. Aerosol Science and Technology 34, 535-549.

Mie, G., 1908. Beiträge zur optik trüber medien, speziell kolloidaler metallösungen. Annalen der Physik Leipzig 330, 377-445.

Moffet, R.C., Prather, K.A., 2009. In situ measurements of the mixing state and optical properties of soot with implications for radiative forcing estimate. Proceedings of the National Academy of Sciences of the United States of America 106, 11872-11877.

Nenes, A., Pilinis, C., Pandis, S.N., 1998. Isorropia: a new thermodynamic equilibrium model for multiphase multicomponent marine aerosols. Aquatic Geochemistry $4,123-152$

Péré, J.C., Mallet, M., Bessagnet, B., Pont, V., 2009. Evidence of the aerosol core-shell mixing state over Europe during the heat wave of summer 2003 by using CHIMERE simulations and AERONET inversions. Geophysical Research Letters 36. doi:10.1029/2009GL037334.

Polichetti, G., Cocco, S., Spinali, A., Trimarco, V., Nunziata, A., 2009. Effects of particulate matter $\left(\mathrm{PM}_{10}, \mathrm{PM}_{2.5}\right.$ and $\left.\mathrm{PM}_{1}\right)$ on the cardiovascular system. Toxicology 261, 1-8.

Pun, B., Seigneur, C., Lohman, K., 2006. Modeling secondary organic aerosol via multiphase partitioning with molecular data. Environmental Science and Technology 40, 4722-4731.

Redemann, J., Russell, P.B., Hamill, P., 2001. Dependence of aerosol light absorption and single-scattering albedo on ambient relative humidity for sulfate aerosols with black carbon cores. Journal of Geophysical Research 106, 485-495.

Reis, S., Pinder, R.W., Zhang, M., Lijie, G., Sutton, M.A., 2009. Reactive nitrogen in atmospheric emission inventories. Atmospheric Chemistry and Physics 9 7657-7677.

Sachdeva, K., Attri, A.K., 2007. Morphological characterization of carbonaceous ggregates in soot and free fall aerosol samples. Atmospheric Environment 42 $1025-1034$

Schaap, M., van Loon, M., ten Brink, H.M., Dentener, F.D., Builtjes, P.J.H., 2004 Secondary inorganic aerosol simulations for Europe with special attention to nitrate. Atmospheric Chemistry and Physics 4, 857-874.

Schmidt, H., Derognat, C., Vautard, R., Beekmann, M., 2001. A comparison of simulated and observed ozone mixing ratios for the summer of 1998 in western Europe. Atmospheric Environment 35, 6277-6297.

Seigneur, C., 2001. Current status of air quality models for particulate matter Journal of the Air and Waste Management Association 51, 1508-1521.

Sheer, V., Kirchner, U., Casati, R., Vogt, R., Wehner, B., Philippin, S., Wiedensohler, A Schneider, N.H.J., Weimer, S., Borrmann, S., 2005. Composition of semi-volatile particles from diesel exhaust. SAE pap.

Shiraiwa, M., Kondo, Y., Moteki, N., Takegawa, N., Miyazaki, Y., Blake, D.R., 2007. Evolution of mixing state of black carbon in polluted air from Tokyo. Geophysical Research Letters 34. doi:10.1029/2007GL029819.

Sloane, C.S., 1984. Optical properties of aerosols of mixed composition. Atmospheric Environment 18, 871-878.

Stern, R., Builtjes, P., Schaap, M., Timmermans, R., Vautard, R., Hodzic, A. Memmesheimer, M., Feldmann, H., Renner, E., Wolke, R., Kerschbaumer, A. 2008. A model inter-comparison study focusing on episodes with elevated PM10 concentrations. Atmospheric Environment 42, 4567-4588.

Tombette, M., Chazette, P., Sportisse, B., Roustan, Y., 2008. Simulation of aerosol optical properties over Europe with a 3-D size-resolved aerosol model: comparisons with AERONET data. Atmospheric Chemistry and Physics 8, 7115-7132.

Vautard, R., Beekmann, M., Desplat, J., Hodzic, A., Morel, S., 2007. Air quality in Europe during the summer of 2003 as a prototype of air quality in a warmer climate. Comptes Rendus Geosciences 339, 747-763.

Vautard, R., Beekmann, M., Roux, J., Gombert, D., 2001. Validation of a hybrid forecasting system for the ozone concentrations over the Paris area. Atmospheric Environment 14, 2449-2461.

Vautard, R., Bessagnet, B., Chin, M., Menut, L., 2005. On the contribution of natura aeolian sources to particulate matter concentrations in Europe: testing hypotheses with a modeling approach. Atmospheric Environment 39, 3291-3303. 
Vautard, R., Martin, D., Beekmann, M., Drobinski, P., Friedrich, R., Jaubertie, A., Kley, D., Lattuati, M., Moral, P., Neininger, B., Theloke, J., 2003. Paris emission inventory diagnostics from ESQUIF airborne measurements and a chemistrytransport model. Journal of Geophysical Research 108.

Vester, B.P., Ebert, M., Barnert, E.B., Schneider, J., Kandler, K., Schütz, L., Weinbruch, L. 2007. Composition and mixing state of the urban background aerosol in the Rhein-Main area (Germany). Atmospheric Environment 41, 6102-6115.

Voshchinnikov, N.V., 2004. Astrophysics and Space Physics Reviews 12, 1.

Wu, X., Seigneur, C., Bergström, R., 1996. Evaluation of a sectional representation of size distributions for calculating aerosol optical properties. Journal of Geophysical Research 101, 19277-19283.
Wu, Z.P., Wang, Y.P., 1991. Electromagnetic scattering for multilayered spheres: recursive algorithms. Radio Science 26, 1393-1401.

Yu, X., Zhu, B., Zhang, M., 2009. Seasonal variability of aerosol optical properties over Beijing. Atmospheric Environment 43, 4095-4101.

Zee, S.C.V.D., Hoek, G., Harssema, H., Brunekreef, B., 1998. Characterization of particulate air pollution in urban and non-urban areas in the Netherlands. Atmospheric Environment 32, 3717-3729.

Zhang, R., Khalizov, A.F., Pagels, J., Zhang, D., Xue, H., McMurry, P.H., 2008. Variability in morphology, hygroscopicity and optical properties of soot aerosols during atmospheric processing. Proceedings of the National Academy of Sciences of the United States of America 105, 10291-10296. 